Lewin, R. A. (1954). J. gen. Microbiol. 11, 459-471.

\title{
The Utilization of Acetate by Wild-type and Mutant Chlamydomonas dysosmos
}

\author{
BY R. A. LEWIN \\ Maritime Regional Laboratory, National Research Council, Halifax, \\ Nova Scotia, Canada
}

SUMMARY: Chlamydomonas dysosmos is capable of normal photosynthetic growth, and of heterotrophic growth in darkness on acetate, pyruvate or lactate. An ultraviolet-induced mutant (D.2075) was isolated which behaved like an obligate photoautotroph. In the presence of $2: 4$-dinitrophenol $\left(5 \times 10^{-5} \mathrm{M}\right)$ or sodium azide $\left(1 \times 10^{-5} \mathrm{M}\right)$, the wild-type organism similarly behaved in growth experiments like an obligate photo-autotroph. Mutant cells oxidized all added acetate to $\mathrm{CO}_{2}$. Wild-type cells oxidized a portion of the substrate, and utilized some of the energy so released for the assimilation of the remainder. There are indications that in the wild type the assimilation of acetate commences only after a period of acetate oxidation. The mutant is believed to be impaired in its ability to effect oxidative assimilation.

The genus Chlamydomonas comprises several hundred species of unicellular green flagellates, all capable of growth by fixing atmospheric carbon dioxide in light. For many of these species photosynthesis apparently constitutes the only possible mode of nutrition, since they are unable to grow heterotrophically on organic sources of carbon. Lewin (1950) investigated obligate autotrophy in C. moerousii Gerloff without reaching any conclusions as to its underlying causes. It seemed that a fresh approach might be made to the problem by starting with a facultatively heterotrophic species and obtaining a mutant strain which lacked the ability to grow in darkness. Ten distinct species in pure culture were tested for ability to grow in darkness on a variety of carbon sources; of these two appeared capable of heterotrophy. They were identified as $C$.dysosmos Moewus (homothallic) and C. debaryana Goroschankin (heterothallic). Both grew sufficiently rapidly in light in simple mineral media with a generation time of 10-12 hr., and neither had specific organic growthsubstance requirements. Since $C$. dysosmos grew more rapidly than the other species when supplied with acetate in darkness, it was selected for further study.

\section{MATERIALS AND METHODS}

The strain used, originally isolated from a sample collected in Long Island by Mr I. C. G. Cooper (see Cooper, 1952) has been tentatively identified as Chlamydomonas dysosmos. Unfortunately it has not been possible to compare characters with the original culture described by Moewus (1931), since the latter was never isolated in pure culture (Moewus, personal communication).

The basal medium (Lewin, 1951) was modified as described below, and solidified with agar $(1 \% ; \mathrm{w} / \mathrm{v})$ for surface cultures. Cells were grown in sterile conditions under constant light and temperature $\left(23^{\circ}\right)$ unless otherwise stated. 
For respirometric studies two modes of cultivation and starvation were found satisfactory:

(a) Liquid cultures (1.0 l.) under constant aeration were grown for 10 days in light (450 f.c.), then aerated for 3 days in darkness in order to deplete endogenous reserves. Cells were separated by centrifugation, washed once, and resuspended in phosphate buffer.

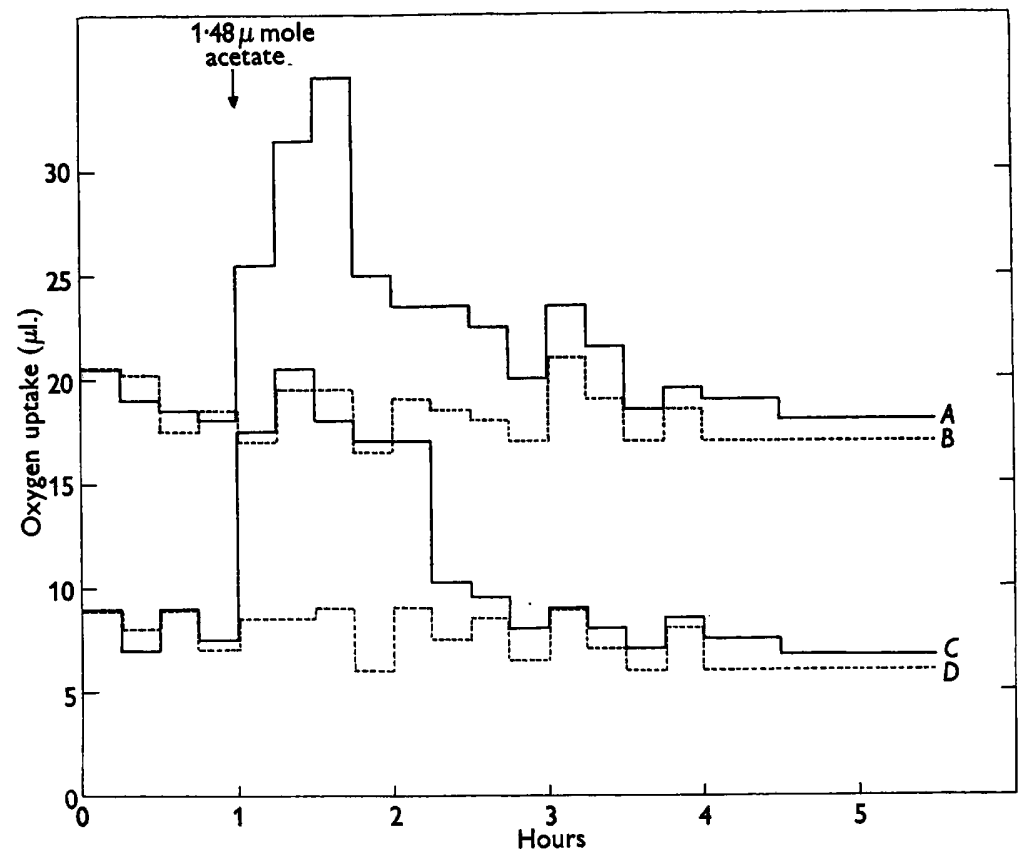

Fig. 1. Effect of composition of growth medium on acetate oxidation by Chlamydomonas dysosmos wild-type cells. $A$, cells grown on mineral agar, with nitrate as sole source of nitrogen, $1.48 \mu$ mole acetate added after $1 \mathrm{hr}$.; $B$, as $A$, buffer added after $1 \mathrm{hr}$; $C$, cells grown on mineral agar $+0.2 \% \mathrm{NH}_{4} \mathrm{Cl}, \mathbf{1} \cdot \mathbf{4 8} \mu$ mole acetate added after $1 \mathrm{hr}$.; $D$, as $C$, buffer added after $1 \mathrm{hr}$. Cell suspensions all of same optical density.

(b) Surface cultures on agar medium in Petri plates were grown for 7 days in light (220 f.c.), then incubated overnight in darkness; this promoted motility and ensured a more uniform suspension. Cells were washed off in buffer and used without further treatment. It was found empirically that the incorporation of an ammonium salt (e.g. $4 \times 10^{-3} \mathrm{M}-\mathrm{NH}_{4} \mathrm{Cl}$ ) markedly reduced postdissimilatory stimulation (see p. 465 and Fig. 1), and for this reason the basal medium was modified accordingly.

Certain physiological differences were observed between the behaviour of cells grown in these two ways (cf. Winzler, 1940). The second method was preferable, since a starvation period was found not to be essential and results were more closely reproducible; it was employed in all experiments reported in this paper.

Mutant D.2075 was obtained by surface irradiation (Lewin, 1952) with ultraviolet radiation from a General Electric 'Disinfectaire' 38 W. tube. Wild- 
type cells from a young culture were spread on an agar medium supplemented with sodium acetate $\left(7.5 \times 10^{-3} \mathrm{M}\right)$, irradiated at a distance of $20 \mathrm{~cm}$. from the ultraviolet source for 10 sec., and then incubated in darkness for 14 days. Cells capable of heterotrophic growth formed colonies, the positions of which were marked with ink; the plates were then illuminated for 4 days to permit growth by photosynthesis of non-heterotrophs. Cultures from this second crop of colonies were tested for ability to grow in darkness on acetate, and among those which lacked this capacity mutant D.2075 was selected for further study. In other respects cells of this mutant strain appeared normal.

Oxygen taken up in respiration was determined manometrically at $25^{\circ}$ using a circular Warburg apparatus (manufactured by Braun, Melsungen, Germany). Each vessel contained 30-100 $\mu \mathrm{l}$. packed cells (centrifuged to constant volume) suspended in $2 \cdot 0 \mathrm{ml}$. phosphate buffer $\left(0 \cdot 1 \mathrm{M}-\mathrm{KH}_{\mathbf{2}} \mathrm{PO}_{4}\right.$, pH 5.6), with $0.2 \mathrm{ml} .10 \% \mathrm{KOH}$ in the centre well. Flasks were shaken at 120 oscillations/min., with an amplitude of $3 \mathrm{~cm}$. After allowing $15 \mathrm{~min}$. for equilibration and about $1 \mathrm{hr}$. to establish endogenous respiration, the substrate, as a sodium salt dissolved in $0.5 \mathrm{ml}$. of phosphate buffer, was tipped in from a side-arm. In determinations of respiratory quotients (Umbreit, Burris \& Stauffer, 1949), alkali was replaced by water in duplicate flasks.

Cell extracts were prepared by the use of a pressure chamber (Milner, Lawrence \& French, 1950). A dense suspension was compressed to $5000 \mathrm{lb}$./sq.in. and released through a controlled nozzle to atmospheric pressure. The resulting homogenate contained few if any intact cells; it was freed from cell debris by centrifugation.

\section{RESULTS}

\section{Growth experiments}

The ability of wild-type cells to grow in darkness was tested on solid media supplemented with ten different carbon sources and adjusted to $\mathrm{pH} 6 \cdot 1$. Each source was tested at three different concentrations, with nitrogen in the form of nitrate, ammonia, or Bacto-Tryptone (Difco). Heterotrophic growth was good in media supplemented with acetate, slight with lactate or pyruvate, and absent with succinate, malate, citrate, glutamate, glycerol, glucose or phosphoglycerate, at concentrations which were not inhibitory in light. Apart from indirect effects on the $\mathrm{pH}$ value of the medium, the sources of nitrogen did not alter these results.

The mutant D.2075 was virtually unable to grow on acetate, lactate or pyruvate in the absence of light. The addition of various concentrations of yeast extract did not restore its ability to utilize acetate for growth, indicating that the mutant was probably not a vitamin-deficient one.

\section{Manometric studies of respiration}

General observations. In an attempt to elucidate the physiological basis for the mutant character, the effects of the addition of substrates or respiratory inhibitors upon respiration of mutant and wild-type cells were investigated manometrically. 
Cells which had been grown in liquid culture, and had not been subjected to a period of starvation after growth in light, showed no detectable stimulation of oxygen uptake on the addition of any substrate. However, after aeration for 3 days in darkness, the endogenous rate was decreased, and stimulation of respiration by acetate was observed.

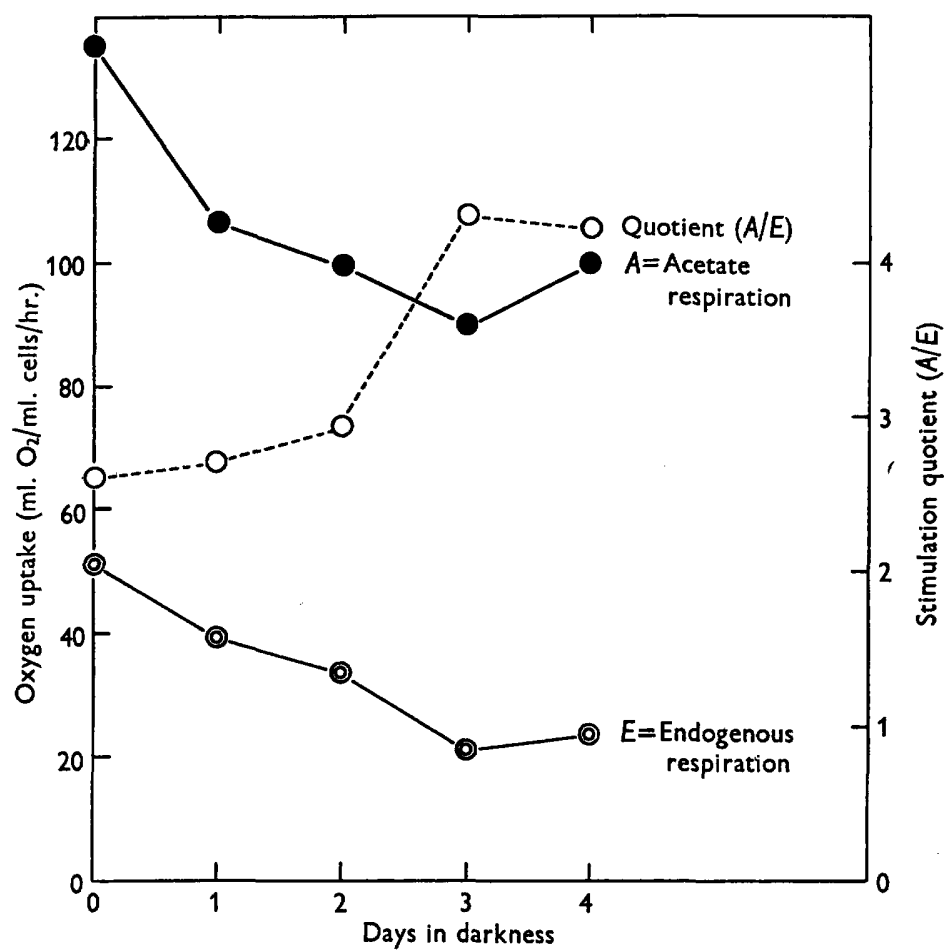

Fig. 2. Effect of incubation in darkness on respiratory rate of Chlamydomonas dysosmos wild-type cells, previously grown in light for 7 days.

Cells grown on solid media showed stimulation by acetate even when not subjected to previous starvation in darkness, though relative stimulation was more marked after such treatment (Fig. 2). Such cells, incubated in darkness overnight, had an endogenous respiratory rate equivalent to $0.5-0.8 \mathrm{ml}$. oxygen $/ \mathrm{ml}$. cells (packed wet volume) $/ \mathrm{hr}$. corresponding to about $50-80 \mathrm{ml}$. $\mathrm{O}_{2} /$ g. cell-N/hr. This rate was approximately doubled, both in wild-type and in mutant cells, on the addition of acetate (Figs. 3, 4). The total volume of oxygen taken up, after correction for endogenous respiration, was proportional to the acetate added within the limits $2 \times 10^{-4} \mathrm{M}$ to $1 \times 10^{-3} \mathrm{M}$. At higher concentrations inhibition effects precluded quantitative determinations. Measurable differences were observed after the addition of quantities as small as $25 \mu$ g. acetic acid per flask. No appreciable stimulation of oxygen uptake occurred after the addition of pyruvate or lactate at any concentration tested.

Stoichiometry of acetate oxidation. The total volume of oxygen uptake during the dissimilation of acetate by cells of the mutant D.2075 was chemically 


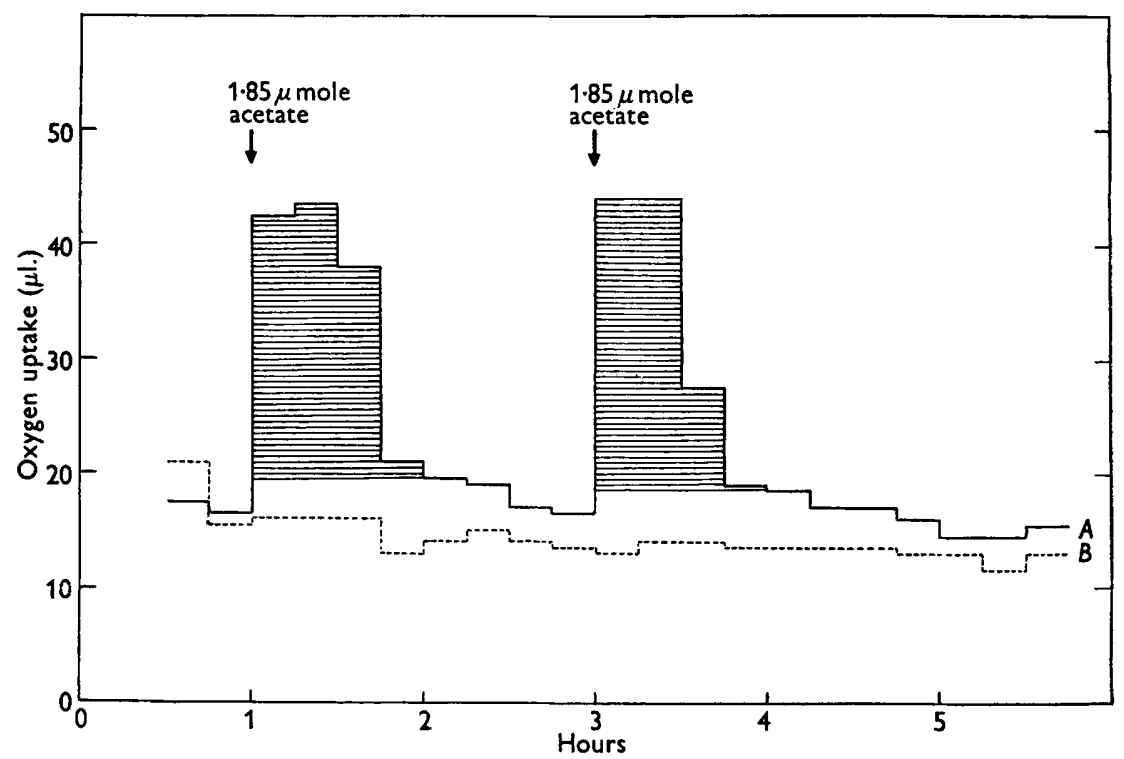

Fig. 3. Effect of two consecutive doses of acetate on respiration of Chlamydomonas dysosmos wild-type cells. $A, 1 \cdot 85 \mu$ mole acetate added after $1 \mathrm{hr}$. and after $3 \mathrm{hr}$; $B$, buffer added after $1 \mathrm{hr}$. and after $3 \mathrm{hr}$.

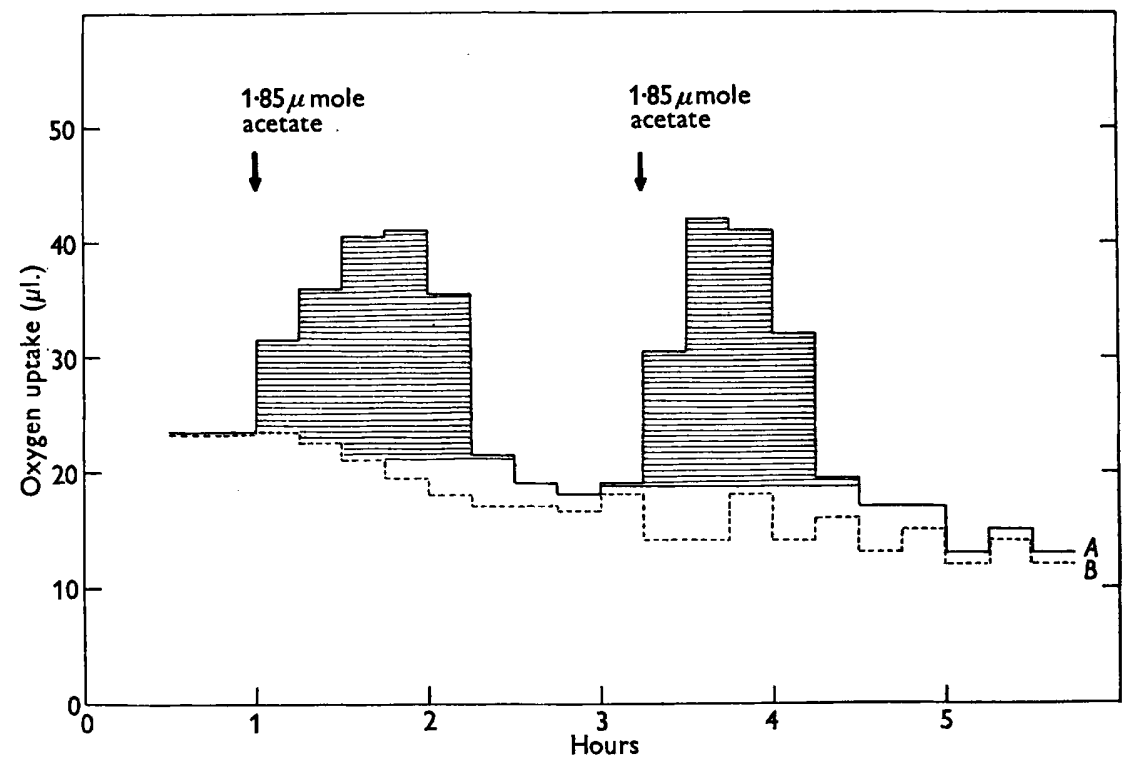

Fig. 4. Effect of two consecutive doses of acetate on respiration of cells of Chlamydomonas dysosmos mutant D.2075. $A, 1.85 \mu$ mole/acetate added after $1 \mathrm{hr}$. and after $3.25 \mathrm{hr}$.; $B$, buffer added after $1 \mathrm{hr}$. and after $3.25 \mathrm{hr}$. 
equivalent to complete oxidation of the acetate supplied, according to the equation:

$$
\mathrm{CH}_{3} \mathrm{COOH}+2 \mathrm{O}_{2} \rightarrow 2 \mathrm{CO}_{2}+2 \mathrm{H}_{2} \mathrm{O} .
$$

The molar ratio of $\mathrm{O}_{2}$ /acetate was $\mathbf{2} \cdot \mathbf{0}$, indicating that no acetate was left to be assimilated: hence the inability of this strain to grow heterotrophically. On the other hand, when wild-type cells were similarly supplied with acetate, the volume of oxygen taken up was found to be dependent on the number of cells per vessel (compare Figs. 5 and 6 ). The $\mathrm{O}_{2}$ /acetate ratio was considerably less than $2 \cdot 0$ when high cell densities were not used. This relationship was unexpected, but could be accounted for on the following postulates: all cells possess a mechanism for oxidizing acetate quantitatively to $\mathrm{CO}_{2}$, and this is the only system operative in the mutant D.2075; in wild-type cells, however,

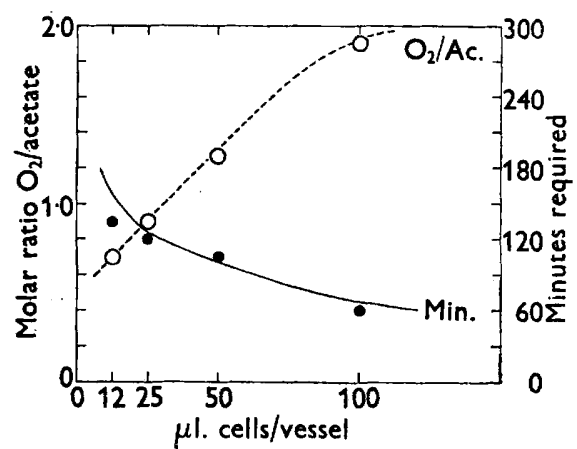

Fig. 5

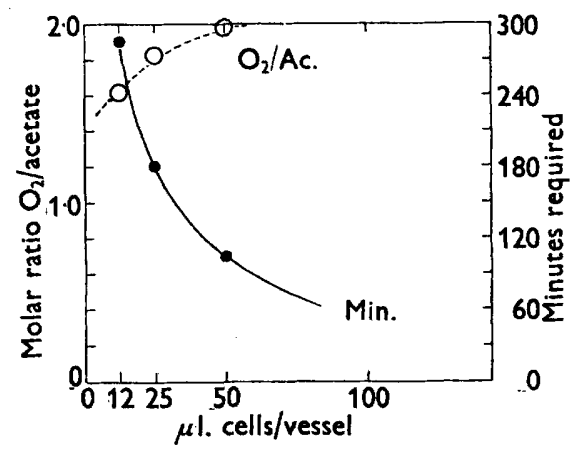

Fig. 6

Fig. 5. Effect of cell density on oxygen uptake (mole oxygen/mole acetate) and time required for acetate utilization in Chlamydomonas dysosmos wild-type cells.

Fig. 6. Effect of cell density on oxygen uptake (mole oxygen/mole acetate) and time required for acetate utilization in cells of Chlamydomonas dysosmos mutant D.2075.

a second mechanism comes into play within an hour or so of contact with acetate, enabling this substrate to be usefully assimilated for anabolism. When the ratio of cells to acetate is high, the acetate is all oxidized before the anabolic mechanism becomes operative; when there are fewer cells, acetate disappears from the medium more slowly, and some remains long enough to permit assimilation via the second system. This hypothesis was tested by measuring the oxygen uptake during the utilization of two equal doses of acetate, added successively to the same sample of wild-type cells. It was found that the $\mathrm{O}_{2}$ /acetate ratio was lower $(1 \cdot 3)$ for the second dose than for the first $(1 \cdot 7)$, indicating that the assimilatory mechanism had, in fact, become more effective as a result of the first period of acetate utilization, and adding support to the suggestion that the assimilatory system takes some time to develop. A similar experiment, carried out with mutant cells, gave a ratio of $2 \cdot 0$ for each dose. It was observed that, both in wild type and mutant, the second dose was utilized rather more rapidly than the first.

Respiration following completion of acetate oxidation. The interpretation of 
the Warburg data tended to be complicated by changes in the concurrent endogenous respiration. On the addition of acetate, oxygen uptake rose rapidly to a higher rate, remained steady for a period, and then fell rapidly as the substrate was used up, However, in both wild type and mutant, the respiratory rate after acetate dissimilation did not return at once to the original level, but for $c .1 \mathrm{hr}$. tended to remain higher than that in parallel control flasks to which only buffer had been added (see Figs. 3, 4). Since the complete oxidation of the added substrate by mutant D.2075, according to equation (1) above, could only just account for the stimulated respiration indicated by the shaded area in the oxygen-uptake curve, some explanation was needed for the subsequent increased rate of respiration. Apparently in Chlamydomonas dysosmos, under the given conditions, endogenous respiration not only continued unsuppressed while cells were oxidizing an externally supplied substrate, but was actually stimulated thereby, proceeding at an augmented rate for an hour or more after the acetate had been consumed. Such an effect might be attributable to an increased activity of enzymes involved in terminal oxidation, or to an increase in the supply of intermediates in the cyclic processes concerned. Inspection of curves published by various workers suggests that this phenomenon is not uncommon-cf. studies on the oxidation of glucose by Escherichia coli (Cook \& Stephenson, 1928) and by Scenedesmus quadricauda (Taylor, 1950).

Respiratory quotients. In both wild-type and mutant cells, the respiratory quotient rose from 0.9 during endogenous respiration to 1.0 during acetate dissimilation. After the exhaustion of the substrate, as indicated by an abrupt drop in the respiratory rate, the R.Q. of the mutant returned at once to $\mathbf{0 . 9}$, but that of wild type remained about unity for $c .1 \mathrm{hr}$. before falling to the original level (see Table 1). This may indicate that after acetate respiration in normal cells there remain intermediates which tend for a while to accelerate the oxidation of endogenous carbohydrate.

Table 1. Respiratory quotients of cells of Chlamydomonas dysosmos wild type and mutant $D .2075$ before, during, and after acetate oxidation

\begin{tabular}{|c|c|c|c|c|}
\hline & Endogenous & $\begin{array}{l}\text { During } \\
\text { acetate } \\
\text { oxidation }\end{array}$ & $\begin{array}{l}\text { 0-1 hr. after } \\
\text { acetate } \\
\text { oxidation }\end{array}$ & $\begin{array}{l}\text { 1-4hr. after } \\
\text { acetate } \\
\text { oxidation }\end{array}$ \\
\hline Wild-type cells & & & & \\
\hline Number of $1 \mathrm{hr}$. determinations & 16 & 6 & 6 & 6 \\
\hline $\begin{array}{l}\text { Respiratory quotient; average } \\
\text { and standard deviation }\end{array}$ & $0.93 \pm 0.055$ & $1 \cdot 00 \pm 0.033$ & $0.98 \pm 0.020$ & $0 \cdot 90 \pm 0$ \\
\hline Iutant D. 2075 cells & & & & \\
\hline $\begin{array}{l}\text { Respiratory quotient; average } \\
\text { and standard deviation }\end{array}$ & $0.88 \pm 0.055$ & $0.99 \pm 0.009$ & $0.90 \pm 0.044$ & $0.87 \pm 0$ \\
\hline
\end{tabular}

Comparison of Chlamydomonas dysosmos with other species. Since the original objective had been to attempt to determine the underlying causes of obligate autotrophy, a comparison was made between $C$. dysosmos, which is normally capable of growth in darkness on acetate media, and $C$. moerousii, 
which is not. Though it was optimistically expected that $C$. moewusii would behave like the mutant D.2075 of $C$. dysosmos, which oxidizes all of the added acetate to $\mathrm{CO}_{2}$, this was found not to be the case. In C. moerousii, like wildtype $C$.dysosmos, the R.Q. for acetate oxidation was $1 \cdot 00$, but the molar ratio $\mathrm{O}_{2}$ /acetate was only $1 \cdot 0-1 \cdot 5$, and did not rise with increasing cell density. The reason for the failure of this species to utilize acetate for growth remains obscure.

In Chlamydomonas debaryana the $\mathrm{O}_{2}$ /acetate ratio was likewise about $1 \cdot 0-1 \cdot 5$, and was apparently unaffected by different cell densities over the range tested. A mutant of this species was obtained by the method described on p. 460. It resembled C. dysosmos D.2075 in being unable to grow on acetate media, but showed no respiratory stimulation whatsoever when supplied with acetate. It is evident that in this case the inability to grow heterotrophically must be attributed to an impairment completely different from that of $C$. dysosmos D.2075 on the one hand and $C$. moerousii on the other.

\section{Effects of various agents on acetate utilization}

Nitrogen sources. The character of the nitrogen source, whether nitrate or an ammonium salt, did not appreciably affect the ability of the wild type or the inability of the mutant to grow heterotrophically on acetate media. Endogenous respiration and acetate oxidation were unaffected by the addition of nitrate $\left(0.01 \mathrm{M}-\mathrm{KNO}_{3}\right)$ or ammonia $\left(0 \cdot 01 \mathrm{M}-\mathrm{NH}_{4} \mathrm{Cl}\right)$ to the phosphate buffer in which the cells were suspended.

Dinitrophenol. The effect of 2:4-dinitrophenol (DNP) on many oxidation systems is apparently to uncouple phosphorylation from oxidation, so that the latter process proceeds with wasteful dissipation of all the chemical energy released, and assimilation is thereby prevented (Simon, 1953). It was found that DNP $\left(5 \times 10^{-5} \mathrm{M}\right)$ or azide $\left(1 \times 10^{-5} \mathrm{M}\right)$, added with acetate in agar media at $\mathrm{pH} 6 \cdot 1$, permitted apparently normal growth of wild-type Chlamydomonas dysosmos in light, but completely inhibited heterotrophic growth in darkness (see Table 2). In this way the effect of the D.2075 mutation was simulated by the action of an inhibitor on wild-type cells. (The fact that $1 \times 10^{-4} \mathrm{M}-\mathrm{DNP}$

Table 2. Effects of 2:4-dinitrophenol and of azide on growth of Chlamydomonas dysosmos wild type and mutant D.2075

\begin{tabular}{|c|c|c|c|c|c|c|}
\hline \multirow[b]{2}{*}{ Inhibitor } & \multirow{2}{*}{$\begin{array}{c}\text { Concentration } \\
\left(\times 10^{-5} \mathrm{M}\right)\end{array}$} & \multirow[b]{2}{*}{ pH } & \multicolumn{2}{|c|}{ Wild type } & \multicolumn{2}{|c|}{ Mutant D. 2075} \\
\hline & & & Light & Darkness & Light & Darkness \\
\hline \multirow{5}{*}{$\begin{array}{l}\text { None } \\
\text { 2:4-Dinitrophenol }\end{array}$} & - & $6 \cdot 9$ & + & + & + & - \\
\hline & $2 \cdot 5$ & 6.7 & + & + & + & - \\
\hline & $5 \cdot 0$ & 6.5 & + & - & + & - \\
\hline & $10 \cdot 0$ & $6 \cdot 1$ & + & - & - & - \\
\hline & $20 \cdot 0$ & $5 \cdot 7$ & - & - & - & - \\
\hline \multirow[t]{3}{*}{ Azide } & 0.4 & 6.9 & + & + & + & - \\
\hline & $0.8-3.2$ & 6.9 & + & - & + & - \\
\hline & 6.4 & 6.9 & - & - & - & - \\
\hline
\end{tabular}

Basal medium: minerals $+7 \cdot 5 \times 10^{-3} \mathrm{M}$-acetate. Growth period: 14 days. $+=$ growth. 
inhibited photosynthetic growth of the mutant, but not of the wild type, is not readily explained.)

Attempts to demonstrate respirometrically the uncoupling of oxidative assimilation by DNP (cf. Clifton, 1946; Winzler, 1940) were complicated by the high rate of endogenous respiration in this organism. $1 \times 10^{-6} \mathrm{M}$-dinitrophenol stimulated endogenous respiration by about $20 \%$, without significantly affecting the rate or extent of acetate oxidation. $5 \times 10^{-6} \mathrm{M}$ or $1 \times 10^{-5} \mathrm{M}$ DNP (pH 5.6) caused the rate of endogenous respiration, as measured by oxygen uptake, almost to double (Figs. 7, 8). The addition of acetate to

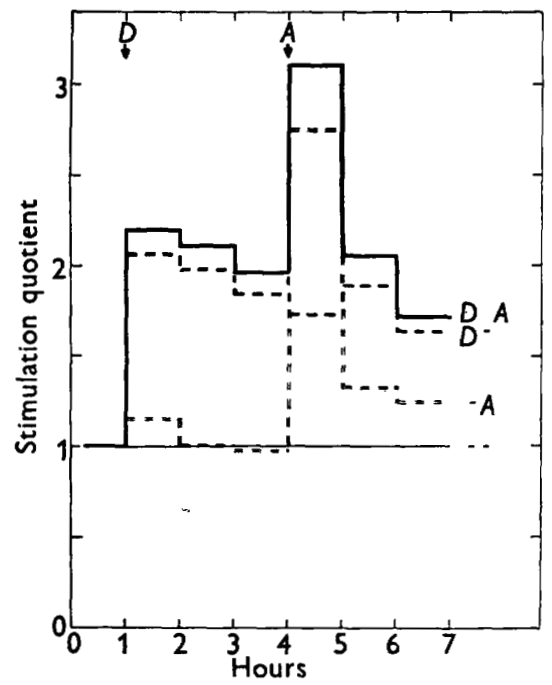

Fig. 7

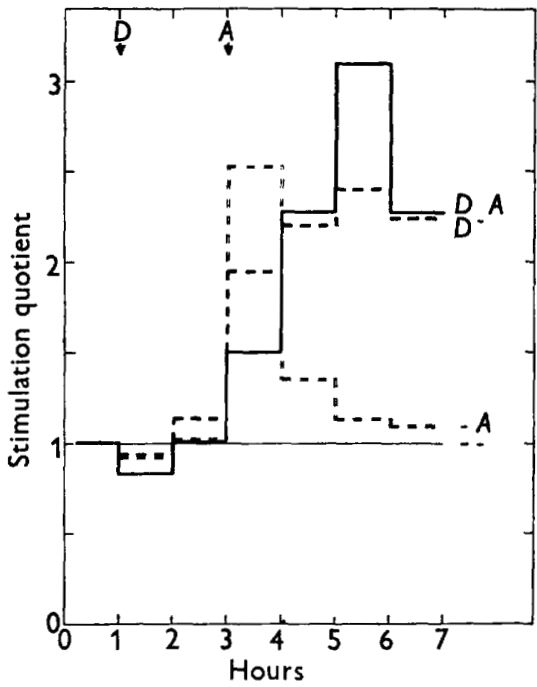

Fig. 8

Fig. 7. Effect of the addition of 2 :4-dinitrophenol (DNP) $\left(5 \times 10^{-6} \mathrm{M}\right)$ on relative respiratory rate of Chlamydomonas dysosmos wild-type cells. $(D-)$ and $(D A), D N P$ added after $1 \mathrm{hr}$.; $(-A)$ and $(D A)$, acetate $(1.85 \mu$ mole) added after $4 \mathrm{hr}$. All rates calculated as ratios of control flasks, to which only buffer was added after $1 \mathrm{hr}$. and after $4 \mathrm{hr}$.

Fig. 8. Effect of the addition of $2: 4$-dinitrophenol $\left(1 \times 10^{-5} \mathrm{M}\right)$ on relative respiratory rate of Chlamydomonas dysosmos wild-type cells. Key: see Fig. 7 .

cells so treated caused the rate of oxygen uptake to rise still further for a period. However, since it could not be established that endogenous respiration continued unchanged during this period, the oxygen consumption attributable to acetate dissimilation (i.e. the $\mathrm{O}_{2}$ /acetate ratio) could not be determined. A still higher concentration of $\mathrm{DNP}, 2 \cdot 5 \times 10^{-5} \mathrm{M}$, decreased endogenous respiration to about a quarter of the control rate, and cells so treated showed no stimulation of oxygen uptake on the addition of acetate.

Cell extracts. To test the possibility that cells of the mutant D.2075 might produce some chemical agent which acted in the same way as DNP (cf. Millerd, Bonner \& Biale, 1953), a cell-free extract of mutant D.2075 was prepared. This extract by itself showed no oxygen uptake, before or after the addition of acetate. In wild-type cells, suspended in extract of mutant and then permitted 
to oxidize acetate, the $\mathrm{O}_{2}$ /acetate ratio remained unchanged. A reciprocal experiment, in which mutant D.2075 cells were treated with wild-type extract, also gave a negative result. Thus in neither case was it possible to demonstrate the presence of a soluble factor, capable of entering intact cells, which might be responsible for the physiological difference between mutant and wild type.

Glycollate and succinate. Anderson (1945) found that, in the presence of glycollic acid, acetate oxidation by Prototheca zopfii resulted in an oxygen uptake in excess of that required for complete dissimilation of the latter substrate; and Goldschmidt \& Powelson (1953) observed a marked stimulation of acetate dissimilation by Staphylococcus aureus in the presence of succinate. Glycollate $\left(2.5 \times 10^{-3} \mathrm{M}\right)$ and succinate $\left(7 \cdot 5 \times 10^{-4} \mathrm{M}\right)$ were therefore tested on acetate dissimilation by Chlamydomonas dysosmos. No stimulation of respiratory rate was observed in either case, nor was the $\mathrm{O}_{2}$ /acetate ratio altered in the presence of these acids.

\section{DISCUSSION}

It appears that the mutant D.2075 of Chlamydomonas dysosmos is unable to grow in darkness heterotrophically because it can only wastefully consume the supplied substrate. Either it lacks the ability to condense acetate in an anabolic mechanism, or it is unable to couple the energy of acetate oxidation in some synthetic pathway. One is reminded of other examples of organisms capable of oxidizing certain organic compounds which nevertheless do not serve as substrates for growth; some of these are summarized in Table 3.

Table 3. Examples of organisms capable of oxidizing a substrate not utilized for growth

\begin{tabular}{|c|c|c|c|}
\hline Organism & Substrate & Observations & Reference \\
\hline Acetobacter suboxydans & Lactate, etc. & $\begin{array}{l}\text { Blocked beyond } \\
\text { acetate }\end{array}$ & King \& Cheldelin (1953) \\
\hline Azotobacter agilis A.3 & Succinate, etc. & $\begin{array}{l}\text { Blocked beyond } \\
\text { pyruvate }\end{array}$ & Karlsson (1950) \\
\hline Escherichia coli & Formate & $100 \%$ oxidized & Cook \& Stephenson (1928) \\
\hline Sphaerotilus natans & Benzoate & $48 \%$ oxidized & Stokes (1954) \\
\hline Chlamydomonas moewusii & Acetate, etc. & $70 \%$ oxidized & Lewin (1950) \\
\hline Navicula pelliculosa & Lactate, etc. & R.Q. $=0.96$ (lactate) $]$ & Lewin (1953) \\
\hline Aspergillus oryzae & $\begin{array}{l}\text { Formate, } \\
\text { acetate, etc. }\end{array}$ & $0.5 \mathrm{M}, \mathrm{pH} 5.5$ & Tamiya (1932) \\
\hline
\end{tabular}

On the other hand, in light on acetate media in an atmosphere free from $\mathrm{CO}_{2}$, growth was as rapid in the mutant as in wild-type cultures. It may be that the cells were oxidizing acetate, and that a proportion of the $\mathrm{CO}_{2}$ so formed was at once fixed intracellularly by normal photosynthetic pathways. However, in the experiments of Allison, Skipper, Reid, Short \& Hogan (1953) it was found that though assimilation of acetate by Nostoc muscorum was considerably accelerated by concomitant photosynthesis, this process was not mediated through $\mathrm{CO}_{2}$ as an intermediate. The possibility remains that cells of Chlamydomonas dysosmos mutant D.2075, though unable to employ the energy from acetate oxidation for acetate assimilation, could nevertheless use light energy for this purpose. 
In wild-type Chlamydomonas dysosmos, though some acetate can be assimilated, the respiratory quotient during acetate oxidation is unity, indicating that under the experimental conditions the cells are not synthesizing appreciable quantities of fat. This seems to conform with the pattern of acetate utilization in Scenedesmus, as reported briefly by Calvin et al. (1951). These workers supplied unstarved cells with labelled acetate $\left({ }^{14} \mathrm{CH}_{3} . \mathrm{COOH}\right)$ in the presence of $4 \% \mathrm{CO}_{2}$. They found that after $30 \mathrm{~min}$. in darkness the labelling appeared in organic acids, chiefly citric and glutamic, indicating the operation of a tricarboxylic acid cycle; in bright light, on the other hand, the acetate was largely assimilated into lipids. Obviously the use of tracers is indicated if more critical studies of Chlamydomonas metabolism are to be carried out, specifically in relation to the products of acetate assimilation.

A value of 1.5 for the ratio of $\mathrm{O}_{2}$ /acetate was obtained for acetate respiration in Escherichia coli by Cook \& Stephenson (1928) and in Mycobacterium ranae by Lindsay, O'Donnell \& Edson (1950), who in each case compensated for simultaneous endogenous respiration. Santer \& Ajl (1954) clearly demonstrated that in Pasteurella pestis such compensation was justifiable, since the rate of endogenous respiration remained unchanged during acetate oxidation. van Niel (1941) obtained a ratio of 1.0 for acetate respiration in Spirillum rubrum, with cells which had been starved to a degree where endogenous respiration was negligible, so that in this case it was not necessary to correct for oxygen uptake in controls. On the other hand, in studies of algae by Barker (1935) with Prototheca zopfii, and by Myers (1947) with Chlorella pyrenoidosa, $\mathrm{O}_{2}$ /acetate ratios of about 1.0 were calculated on the assumption that endogenous respiration was suppressed during the period of acetate oxidation. This cannot be true for Chlamydomonas dysosmos for the following reason. In the mutant D.2075, or in dense suspensions of wild-type cells, the addition of acetate causes a net increase in oxygen uptake equivalent to 2 mole $\mathrm{O}_{2} / \mathrm{mole}$ substrate-i.e. the latter is completely oxidized. If one were to assume that endogenous respiration is suppressed during acetate oxidation, one would calculate an $\mathrm{O}_{2}$ /acetate ratio far exceeding $2 \cdot 0$, which is chemically impossible.

Under the action of certain agents, assimilatory processes can be dissociated from respiration in many organisms. Thus Clifton (1946) observed that, in the presence of suitable concentrations of DNP, assimilation could be dissociated from respiration so that the oxidation of substrates went virtually to completion. Concentrations of DNP or azide which had a negligible effect on the rate of endogenous respiration in Escherichia coli or Pseudomonas calco-acetica raised the $\mathrm{O}_{2}$ /acetate ratio from 1.5 to 1.9 . Winzler (1940) obtained similar results using Saccharomyces cerevisiae, in which the $\mathrm{O}_{2}$ /acetate ratio was raised from 1.3 to $2 \cdot 0$. Attempts to demonstrate such an effect in Chlamydomonas dysosmos were complicated by the high rate of endogenous respiration in this organism (see p. 467). Nevertheless, the fact that $5 \times 10^{-5} \mathrm{M}$-dinitrophenol inhibited heterotrophic growth on acetate, while permitting photosynthetic growth, suggests that here, too, oxidative assimilation may be inhibited by this agent.

Millerd et al. (1953) presented evidence for the presence in ripe avocado 
pears of an agent which acts in a fashion similar to DNP. Cell-free preparations of pre-climacteric fruits were capable of coupling substrate oxidation with esterification of inorganic phosphate, whereas similar preparations of postclimacteric fruits were unable to form high-energy phosphate compounds in this way. The difference in behaviour was traced to a soluble factor present in the post-climacteric fruits. No factor of this sort could be detected in cells of the Chlamydomonas dysosmos mutant D.2075.

Finally, it seems that in Chlamydomonas dysosmos there are two systems for dealing with acetate, one dissimilatory and the other assimilatory. The second system is only operative from wild-type cells after a lag, and is apparently absent altogether from the mutant D.2075. Barron \& Ghiretti (1953) adduced evidence indicating that acetate oxidation in various organisms may take place either through the Krebs tricarboxylic acid cycle, or by an alternative pathway which involves dicarboxylic acids. Krebs, Gurin \& Eggleston (1952) suggested that in yeast the latter system may mediate the oxidative dissimilation of the substrate, whereas the tricarboxylic acid cycle is responsible for the provision of metabolic intermediates. If in fact $C$. dysosmos normally possesses two systems of this sort, it is possible that the mutant character of D.2075 lies in some impairment of the Krebs cycle. Cultures of C. dysosmos, wild type and mutant D.2075, have been deposited with the algal type culture collections at Cambridge, Fngland, and at Bloomington, Indiana, U.S.A.

The author is deeply indebted to $\mathrm{Dr}$ J. C. Lewin for many valuable suggestions, to Miss R. H. Mintz for excellent technical assistance, and to Dr E. G. Young and Dr J. G. Kaplan for a critical reading of the manuscript.

This paper is issued as N.R.C. no. 1896.

\section{REFERENCES}

Allison, R. K., Skipper, H. E., Reid, M. R., Short, W. A. \& Hogan, G. L. (1953). Studies on the photosynthetic reaction. I. The assimilation of acetate by Nostoc muscorum. J. biol. Chem. 204, 197.

Anderson, E. M. (1945). Metabolism of Prototheca zopfii. J. gen. Physiol. 28, 297.

Barker, H. A. (1935). The metabolism of the colorless alga, Prototheca zopfii Krüger. J. cell. comp. Physiol. 7, 73.

Barron, E. S. G. \& GHiretTr, F. (1953). The pathways of acetate oxidation. Biochim. Biophys. Acta, 12, 239.

Calvin, M., Bassham, J. A., Benson, A. A., Lynch, V. H., Ouelnet, C., Schou, L., Stepka, W. \& Tolbert, N. E. (1951). Carbon dioxide assimilation in plants. Symp. Soc. exp. Biol. 5, 284.

Curfton, C. E. (1946). Microbial assimilations. Advanc. Enzymol. 6, 269.

Cook, R. P. \& Stephenson, M. (1928). Bacterial oxidations by molecular oxygen. I. The aerobic oxidation of glucose and its fermentation products in its relation to the viability of the organism. Biochem. J. 22, 1368.

Cooper, I. C. G. (1952). Chlamydomonas dysosmos Moewus in Staten Island. Proc. Staten Is. Inst. 14, 74.

Goloschmid, M. C. \& Powelson, D. M. (1953). Effect of the culture medium on the oxidation of acetate by Micrococcus pyogenes var. aureus. Arch. Biochem. Biophys. 46, 154.

Karlsson, J. L. (1950). Metabolic studies of Azotobacter agilis by the use of a mutant deficient in pyruvic oxidase. J. biol. Chem. 183, 549 . 


\section{Use of acetate by Chlamydomonas dysosmos}

KIng, T. E. \& Cheldelin, V. H. (1953). Sources of energy and the dinitrophenol effect in the growth of Acetobacter suboxydans. J. Bact. 66, 581.

Krebs, H. A., Gurin, S. \& Eggleston, L. V. (1952). The pathway of oxidation of acetate in baker's yeast. Biochem. J. 51, 614.

LewiN, J. C. (1950). Obligate autotrophy in Chlamydomonas moerousii. Science, $112,652$.

LEwiN, J. C. (1953). Heterotrophy in diatoms. J. gen. Microbiol. 9, 305.

LEwIN, R. A. (1951). Isolation of sexual strains of Chlamydomonas. J. gen. Microbiol. $5,926$.

LEWIN, R. A. (1952). Ultraviolet induced mutations in Chlamydomonas moerousii Gerloff. J. gen. Microbiol. 6, 233.

Lindsay, M., O'Donnelu, T. V. \& EDson, N. L. (1950). The oxidation of pyruvate and fatty acids by Mycobacterium ranae. Biochem. $J .46,248$.

Moewus, F. (1931). Neue Chlamydomonaden. Arch. Protistenk. 75, 284.

Mrluerd, A., Bonner, J. \& Biale, J. B. (1953). The climacteric rise in fruit respiration as controlled by phosphorylative coupling. Plant Physiol. 28, 521.

Mirner, H. W., Lawrence, N. S. \& French, C. S. (1950). Colloidal dispersion of chloroplast material. Science, 111, 633.

Myers, J. (1947). Oxidative assimilation in relation to photosynthesis in Chlorella. J. gen. Physiol. 30, 217.

Santer, M. \& AJl, S. (1954). Metabolic reactions of Pasteurella pestis. I. Terminal oxidation. J. Bact. 67, 379.

Simon, E. W. (1953). Mechanisms of dinitrophenol toxicity. Biol. Rev. 28, 453.

STokEs, J. L. (1954). Studies on the filamentous sheathed iron bacterium Sphaerotilus natans. J. Bact. 67, 278.

TAMrYa, H. (1932). Über die Verwendbarkeit von verschiedenen Kohlenstoffverbindungen im Bau- und Betriebsstoffwechsel der Schimmelpilze. Studien über die Stoffwechselphysiologie von Aspergillus oryzae. IV. Acta Phytochim. 6, 1.

TAYLOR, F. J. (1950). Oxidative assimilation of glucose by Scenedesmus quadricauda. J. exp. Bot. 1, 301.

Umbreit, W. W., Burris, R. H. \& Stauffer, J. F. (1949). Manometric Techniques and Tissue Metabolism, 2nd ed. Minneapolis: Burgess Publishing Co.

vaN NIEL, C. B. (1941). The bacterial photosyntheses and their importance for the general problem of photosynthesis. Adv. Enzymol. 1, 263.

WiNZLER, R. J. (1940). The oxidation and assimilation of acetate by baker's yeast. J. cell. comp. Physiol. 15, 343.

(Received 19 June 1954) 